\title{
Endobronchial valves: an emerging therapeutic alternative to VATS for the surgical management of advanced emphysema
}

This article was published in the following Dove Press journal:

International Journal of General Medicine

6 December 2010

Number of times this article has been viewed

\section{Shailendra Kapoor \\ Family Practitioner, Knoxville, TN, USA}

Correspondence: Shailendra Kapoor

915 Ashbrooke Way,

Knoxville, TN 37923, USA

Email shailendrakapoor@yahoo.com
I read with great interest the recent article by Lin and Luh on the treatment of patients with bullous emphysema with video-assisted thoracoscopic surgery. ${ }^{1}$ The topic is highly interesting. However endobronchial valves have emerged over the past few years as a highly effective and efficient alternative to video-assisted thoracoscopic surgery.

For instance, Sciurba et al have recently demonstrated the effectiveness of endobronchial valves in patients with advanced stages of emphysema. ${ }^{2}$ Similarly, air leaks such as those resulting in subcutaneous emphysema and those secondary to iatrogenic chest tube placement can be effectively treated with endobronchial valves. ${ }^{3}$ Endobronchial valves can also be used for the closure of broncho-pleural fistulas in patients with pleural empyema. ${ }^{4}$ Endobronchial valves can also be used for producing atelectasis in affected lobes in patients afflicted with tuberculosis, thus limiting the spread of infection. ${ }^{5}$ Recent studies also suggest that endobronchial valves may play a major role in lung transplant surgeries in the near future. ${ }^{6}$

The above examples clearly illustrate the increasing role and efficacy of endobronchial valves and the need for further studies to identify their potential role in the treatment of other pulmonary conditions besides emphysema.

\section{References}

1. Lin KC, Luh SP. Video-assisted thoracoscopic surgery in the treatment of patients with bullous emphysema. Int J Gen Med. 2010;3:215-220.

2. Sciurba FC, Ernst A, Herth FJ, et al. A randomized study of endobronchial valves for advanced emphysema. N Engl J Med. 2010;363:1233-1244.

3. Abu-Hijleh M, Blundin M. Emergency use of an endobronchial one-way valve in the management of severe air leak and massive subcutaneous emphysema. Lung. 2010;188:253-257.

4. Santini M, Fiorelli A, Vicidomini G, Laperuta P, di Crescenzo VG. Iatrogenic air leak successfully treated by bronchoscopic placement of unidirectional endobronchial valves. Ann Thorac Surg. 2010;89: 2007-2010.

5. Levin AV, Tseimakh EA, Zimonin PE, et al. Use of an endobronchial valve in complex treatment of patients with infiltrative pulmonary tuberculosis. [Russian] Probl Tuberk Bolezn Legk. 2008;(9):29-32.

6. Kemp SV, Carby M, Cetti EJ, Herth FJ, Shah PL. A potential role for endobronchial valves in patients with lung transplant. J Heart Lung Transplant. 2010 Aug 11. [Epub ahead of print].

International Journal of General Medicine

\section{Publish your work in this journal}

The International Journal of General Medicine is an international peer-reviewed open-access journal that focuses on general and internal medicine, pathogenesis, epidemiology, diagnosis, monitoring and treatment protocols. The journal is characterized by the rapid reporting of reviews, original research and clinical studies across all disease areas.
A key focus is the elucidation of disease processes and management protocols resulting in improved outcomes for the patient.The manuscript management system is completely online and includes a very quick and fair peer-review system. Visit http://www.dovepress.com/ testimonials.php to read real quotes from published authors. 